\title{
Prior and future earthquake effects in Valdivia, Chile
}

\author{
Efectos previos y futuros del terremoto de Valdivia, Chile
}

Fecha de envío: 9 de enero 2020

Fecha de aceptación: 4 de mayo 2020

\section{Robb Eric S. Moss ${ }^{1,2}$ and Ricardo Moffat ${ }^{2,3}$}

${ }^{1}$ Department of Civil and Environmental Engineering, California Polytechnic State University, San Luis Obispo, California 93407, USA,rmoss@calpoly.edu

${ }^{2}$ LMMG Geotecnia Limitada, Santiago, Chile, contacto@lmmg.cl

${ }^{3}$ Facultad de Ingeniería y Ciencias, Universidad Adolfo Ibáñez, Diagonal Las Torres 2700, Peñalolén, Región Metropolitana de Santiago, Chile, ricardo.moffat@uai.cl

The $1960 M_{w}=9.5$ subduction earthquake that struck Chile had an epicenter close to the city of Valdivia. There was widespread damage due both strong ground shaking from the earthquake and from the subsequent tsunami. These earthquake effects are examined from a modern perspective and the potential for future effects are discussed. Based on recent cone penetration measurements (sCPTu) the ground failures observed along the waterfront and other locations in Valdivia are attributed to cyclic failure of sensitive "clayey" soils and/or liquefaction of saturated "sandy" soils. If similar strong shaking is experienced in future earthquakes, similar ground failures would be expected. The regional subsidence in and around Valdivia following the 1960 earthquake is attributed to tectonic deformations and is corroborated with the same mechanism from the recent $2010 M_{w}=8.8$ earthquake. If a similar magnitude event is experienced in the future, similar subsidenceluplift are expected which appear to follow a harmonic function. The goal of investigating these past earthquake effects and potential future effects is to help minimize the earthquakes risks in Valdivia and other regions subjected to the same hazards.

Keywords: earthquake, CPTu, liquefaction, cyclic failure, co-seismic deformation
El terremoto de subducción $M_{w}=9.5$ que golpeó a Chile en 1960, tuvo su epicentro cercano a la ciudad de Valdivia. Hubo daño extendido debido tanto al fuerte movimiento sísmico como al siguiente tsunami generado. Los efectos del terremoto son examinados desde una perspectiva moderna $y$ el potencial de futuros efectos es discutido. Basados en recientes mediciones del ensayo de penetración de cono (sCPTu), la falla del terreno observada a lo largo de la costanera y otras ubicaciones de Valdivia son atribuidas a la falla cíclica de "arcilla" sensitiva y/o licuefacción de "arenas" saturadas. Si un nivel de movimiento similar es observado en futuros terremotos, se observarían fallas del terreno similares a las observadas. La subsidencia regional en y alrededor de Valdivia luego del terremoto de 1960 es atribuida a la deformación tectónica y ha sido corroborada con el mismo mecanismo en el reciente terremoto de $M_{w}=8.8$ del 2010. Si un evento similar se genera en el futuro, similar hundimiento/levantamiento son esperados lo que parecen seguir una función armónica. Investigar los efectos pasados de terremotos y el potencial efecto de futuros eventos, ayuda a minimizar el riesgo de terremotos en Valdivia y otras regiones bajo riesgos similares.

Palabras clave: terremoto, CPTu, licuefacción, falla cíclica, deformación co-sísmica

\section{Introduction}

Valdivia is a city that was founded as early as 1552 by Spanish explorers. It was cited on a hill 15 to $16 \mathrm{~m}$ above sea level and surrounded by water on all sides lending to the name "The City of the Lake" (Retamal and Kausel, 1969). The first record of earthquake damage came from the 1575 event and subsequent tsunami. The city was destroyed completely in 1599 by the native inhabitants, but rebuilt again in its current location in 1779. At the time of the 1960 earthquake the city held a population of 72400 .

Valdivia experienced three distinct hazards due to the 1960 earthquake; strong ground shaking, tectonic subsidence, and tsunami inundation. This study will focus on the first two by characterizing the ground failure due to the strong 
shaking, and discussing the spatial distribution of coseismic tectonic deformations.

The city is underlain by sediments that are dominated by interlayered sands and silts, with the silts having moderate to high plasticity. The surface topography of the city has been modified over time; high spots were leveled and low spots were filled. The filling has been performed in and uncontrolled manner (i.e., no compaction) using native materials generally classified as low and high plastic silts (ML to $\mathrm{MH}$ ). The filled regions were strongly correlated with observed damage and ground failure after the 1960 event (Duke and Leeds, 1963). Ground failure mechanisms were not well understood at the time, but more recent research defines the seismic failure mechanisms in plastic fined-grained soils as cyclic failure and in saturated granular soils as liquefaction. In this study we detail how liquefaction and/or cyclic failure resulted in the observed damage throughout Valdivia and the hazard that it currently presents today.

Co-seismic tectonic deformations of the ground surface elevation has components of vertical and horizontal movement and are common in large earthquakes such as the 1960 event. If the vertical shift results in regional tectonic subsidence, this then can increase the tsunami hazard in low lying port regions (Kelson et al., 2012). Some of the tsunami damage from 1960 tsunamic can be directly attributed to this subsidence in the Valdivia and other regions.

\section{0 event earthquake effects}

The 1960 Chilean earthquake is considered the largest event to have occurred in modern history (USGS, 2017). This earthquake impacted towns as far north as Talca and as far south as Chiloe and caused damage over a region of hundreds of thousands of square kilometers. It resulted in deaths in the thousands and damage in the hundreds of millions of dollars. The resulting tsunami impacted southern Chile, Hawaii, Japan, the Philippines, China, eastern New Zealand, southeast Australia and the Aleutian Islands. In this paper we focus our study on the earthquake effects in Valdivia.

The waterfront of Valdivia is underlain primarily by silty sandy soil $\left(\mathrm{Q}_{\mathrm{v} 6}\right)$ that has the following properties as measured by borings from IDIEM (1961) and Duke and
Leeds (1963):

- Water content $\left(w_{\mathrm{c}}\right)$ of 40 to $70 \%$,

- Liquid Limit (LL) of 50 to $70 \%$,

- Plastic Limit (PL) of 10 to $30 \%$,

- Unconfined Compressive Strength UCS of 100 to 200 $\mathrm{kPa}$,

- Sensitivity $\left(S_{\mathrm{t}}\right)$ of 2 to 5 ,

- USCS classification MH

The soil is described as recent (Quaternary) water-deposited alluvium and artificial fill composed of fine sand, silt, and clay with some marine fragments (Duke and Leeds, 1963). The origin of the soil is that of volcanic deposits that have been weathered and transported to their current location of the Valdivia River and Calle Calle River estuary.

Ground failure due to strong ground shaking was observed throughout the city of Valdivia. Figure 1 shows the ground cracking and slumping observed along the embarcadero, typical of damage throughout the city. The largest deformations and/or highest concentration of building damage is strongly correlated with regions where fill was placed prior to construction. Vertical deformations were typically on the order of 0.15 to $0.45 \mathrm{~m}$, with some locations experiencing up to $0.80 \mathrm{~m}$. No evidence of liquefaction (i.e., sand ejecta) was observed with any of the deformations in Valdivia (Duke and Leeds, 1963; Retamal and Kausel, 1969). However, recent re-evaluation

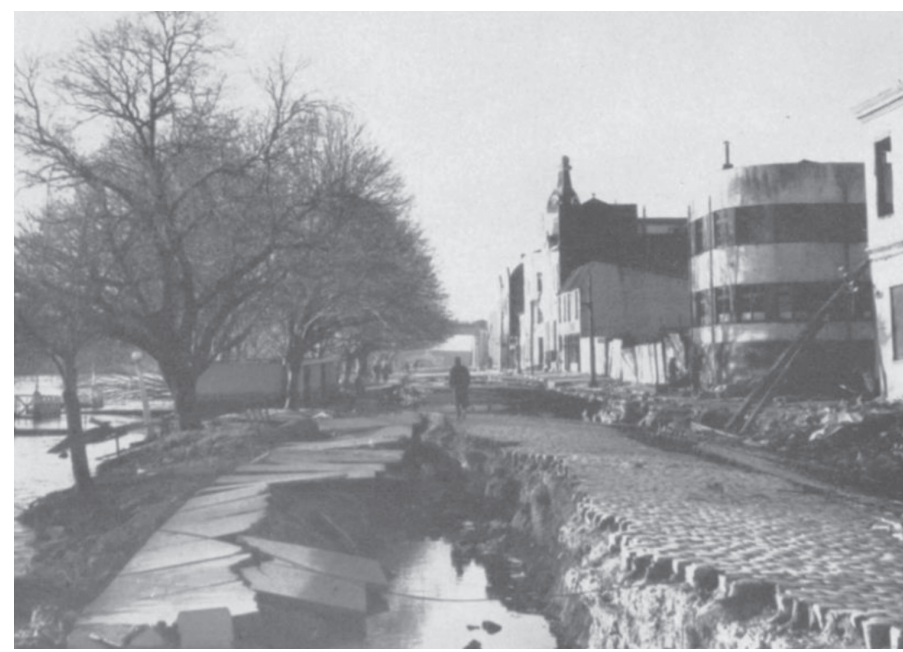

Figure 1: Ground failure along the Valdivia embarcadero from the 1960 Earthquake (Duke and Leeds, 1963) 
(Gonzalez and Verdugo, 2014) questions if the researchers at the time knew what to look for and that liquefaction may have been a failure mechanism. The advent of liquefaction research and understanding of this phenomenon began following the 1964 Alaska and 1964 Niigata Earthquakes. To discern what failure mechanism is causative we examine recent subsurface investigations in Valdivia using the cone penetration test (CPT).

A detailed survey following the 1960 earthquake found that $1.8 \mathrm{~m}$ of subsidence in Valdivia can be attributed to co-seismic tectonic deformations (Retamal and Kausel, 1969). These widespread deformations exacerbated the tsunami hazard by placing low lying areas within reach of the incoming tsunami wave. In this paper we compare more recent measurements of co-seismic deformations from other subduction events and describe how that applies to the Valdivia region.

\section{Cyclic failure of plastic soils}

Sensitive plastic soils have been found to be susceptible to seismic failure. The deformations from cyclic failure are typically not as large as those caused by liquefaction, yet they can still cause damage to engineered features. Sensitivity $\left(S_{t}\right)$ is the measure of the peak undrained shear strength $\left(s_{u, \text { peak }}\right)$ to the residual or remolded $\left(s_{u, \text { remolded }}\right)$ shear strength. The term "clayey" here refers to any soil with enough plasticity to make it not susceptible to liquefaction, and for Valdivia that includes plastic silts. Susceptibility criteria for liquefaction are often contentious, but generally soils that have a plasticity index (PI) greater than 8 to 12 , and a water content less than the liquid limit are considered not liquefiable (Seed et al., 2003; Bray and Sancio, 2006; Idriss and Boulanger, 2008; Moss et al., 2011) which means that these soils may be susceptible to cyclic failure. Based on the soil properties quoted in the prior section the silty soil would generally be considered non-liquefiable, however there may be pockets or lenses of low plastic silts and fine sands that could response to strong ground shaking through liquefaction.

To assess the likelihood of cyclic failure deformations the static driving shear stresses $\left(\tau_{o}\right)$ are compared to the undrained shear strength $\left(s_{u}\right)$ of the soil. Boulanger and Idriss (2004) present methods for assessing the triggering of cyclic failure based on: 1) laboratory testing, 2) field testing, and 3) estimate method. In this paper we focus on the field testing method because we have current sCPTu measurements in Valdivia. Triggering of cyclic failure is defined as when the cyclic stress ratio (CSR) exceeds the cyclic resistance ratio $(C R R)$. The cyclic stress ratio can be calculated using site response analysis but it is more commonly estimated using the simplified equation (Seed and Idriss, 1971):

$$
\operatorname{CSR}=\frac{\tau_{\text {avg }}}{\sigma_{v}^{\prime}} \approx 0.65 a_{\max } \frac{\sigma_{v}}{\sigma_{v}^{\prime}} r_{d}
$$

where $\tau_{a v g} / \sigma_{v}^{\prime}$ is the average shear stress at the depth of the layer in question normalized by the vertical effective stress, $\sigma_{v} \sigma_{v}^{\prime}$ is the vertical total stress at the depth of the layer in question normalized by the vertical effective stress, $a_{\max }$ is the peak ground acceleration, and $r_{d}$ is the non-linear shear mass participation factor that modifies the ground shaking from the surface to the depth of interest.

To determine the cyclic resistance ratio of plastic soil to cyclic failure Boulanger and Idriss (2004) and Idriss and Boulanger (2008) provide the following equation for average clays:

$$
C R R \approx 0.8 \frac{s_{u}}{\sigma_{v}^{\prime}} K_{\alpha} M S F
$$

where 0.8 is an adjustment for field $2 \mathrm{D}$ conditions versus laboratory simple shear $1 \mathrm{D}$ conditions, $s_{u} / \sigma_{v}^{\prime}$ is the undrained shear strength normalized by the vertical effective stress, $K_{\alpha}$ adjusts for driving shear stress conditions, and $M S F$ is the magnitude scaling factor that adjusts for duration from different magnitude events. Values used are based on Boulanger and Idriss (2004).

The undrained shear strength $s_{u}$ of plastic soil can be calculated from the uncorrected cone penetration $\left(q_{c}\right)$ tip resistance. A semi-theoretical relationship between the tip resistance and the undrained shear strength of clays is (Lunne et al., 1997):

$$
s_{u}=\frac{q_{t}-\sigma_{v}}{N_{k}}
$$

where $q_{t}$ is the pore pressure $(u)$ corrected tip resistance $\left(q_{t}\right.$ $\left.\sim q_{c}+0.2 u\right), \sigma_{v}$ is the total vertical stress, and $N_{k}$ is the cone factor. The cone factor is somewhat soil dependent and typically takes a value between 10 and 18 , with 12 to 14 
a useful median range (Robertson and Cabal, 2015). The undrained shear strength measured with the cone is a high strain measure of shear strength, but it does not measure the residual strength of the soil. To do that a vane shear test (VST) is the most accurate field test. In many situations the vane shear can be conducted directly adjacent to the cone penetration test to measure the peak $\left(s_{u, p e a k}\right)$ versus the residual $\left(s_{u, \text { residual }}\right)$ shear strength to obtain the sensitivity $S_{t}=s_{u, \text { peak }} / s_{u, \text { residual }}$. A sensitivity of 1.2 or greater indicates a sensitive soil that may be susceptible to cyclic failure (Holtz et al., 2011). The CPT, however, can provide an estimate of the sensitivity by assuming that the sleeve friction $(f)$ measures the remolded shear strength of the soil (Robertson and Cabal, 2015).

$$
S_{t}=\frac{s_{u}}{f_{s}}
$$

Recent subsurface investigations (per LMMG Geotecnia Limitada) have used $\mathrm{SCPTu}$ to measure the in situ conditions of soils around Valdivia. In this study we look at two soundings (Figure 2) that were recently performed near the embarcadero (coincident with Figure 1) that experienced ground failure in the 1960 seismic event. In this zone it has been found deposits of silty sands as it is shown in Figure 2 according to Arenas et al. (2005).

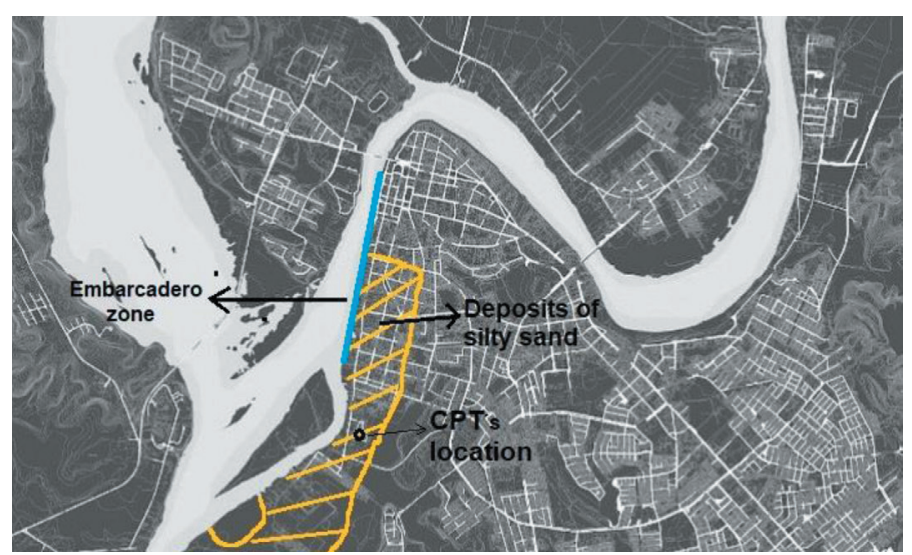

Figure 2: Location of CPTu soundings performed on silty soil deposit

The profile in Figure 3 indicates interlayered variable soil. Trends show sandy regions in the 1.0 to $3.0 \mathrm{~m}$ depth and 5.5 to $8.5 \mathrm{~m}$ depth as indicated by relatively high tip resistance and corresponding low friction ratio. The region from 3.0 to $5.0 \mathrm{~m}$ depth contains layers of plastic silts/clays as indicated by the relatively low tip resistance and variable to high friction ratio. Based on the elevation of the site and the elevation of the nearby water way the depth to the water table was estimated at $2 \mathrm{~m}$ below the ground surface.

To evaluate the feasibility of seismic induced ground deformation due to the plastic fines the CPTu data in Figure 3 was used to calculate the cyclic resistance per equation (2). To do that the undrained shear strength of the soil was first calculated per equation (3) where a median cone factor $N_{k}$ of 12 was used (Robertson and Cabal, 2015). The unit weight of the soils was assumed to be roughly $18 \mathrm{kN} / \mathrm{m}^{3}$.

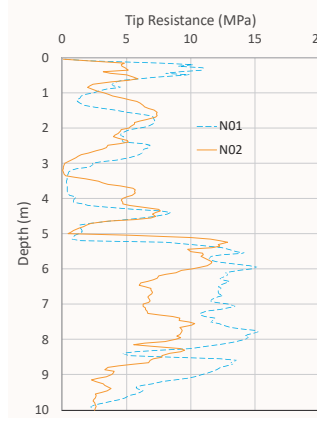

a)

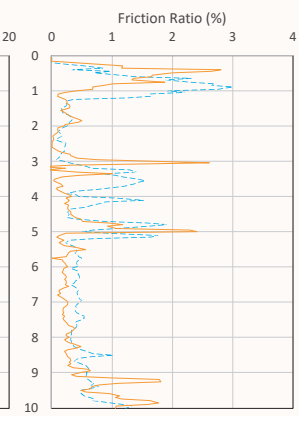

b)

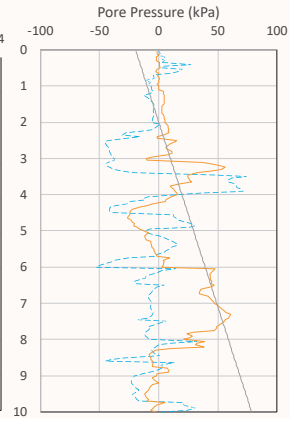

c)
Figure 3: Two sCPTu soundings performed along the embarcadero in downtown Valdivia, showing measurements of: a) cone tip resistance, b) friction ratio, and c) pore pressure. The elevation of the site is $+8 \mathrm{~m}$ above sea level and the water table has been estimated at a depth of $2 \mathrm{~m}$ as shown in the pore pressure plot.

The simplified approach calculates cyclic resistance ratio $C R R$ and cyclic resistance ratio $C S R$ based on nominal $M$ $=7.5$ loading conditions. These conditions are modified for magnitudes other than 7.5 using the nonlinear shear mass participation factor $r_{d}$ on the loading side and magnitude scaling factor $M S F$ on the resistance side. Neither of these corrections have been derived from data from $M$ $\sim 9.5$ earthquakes such as the 1960 Chilean event, so to approximate that event the curves for MSF and $r_{d}$ were extrapolated using the methods put forth by Idriss and Boulanger (2008). There is the potential for significant error extrapolating and using one method of MSF and $r_{d}$, but we are attempting a back-analysis feasibility study so rough order of magnitude estimates are acceptable in this case.

Figure 4 shows the cyclic resistance results. Figure $4 b$ shows the estimate of the cyclic resistance of the clayey soil versus the cyclic stress from $0.5 \mathrm{~g}$ peak ground acceleration. The estimated value of PGA $=0.5 \mathrm{~g}$ was obtained from a probability of $10 \%$ of being exceeded in 50 years (corresponding to 475 years return period as shown by Leyton et al., 2009). What can be seen is that the loading is higher than the resistance over a half a meter thick layer in 
the 3.0 to $4.0 \mathrm{~m}$ depth range. The corresponding sensitivity of the soil is 2 or higher in this region as well. Based on these rough calculations a large magnitude event such as the 1960 event that produced peak ground accelerations upwards of $0.5 \mathrm{~g}$ could cause the clayey soil to fail, and the sensitivity indicates that once failed the soil would exhibit strain softening that could result in co-seismic and/or postseismic deformations until the final static shear stresses are balanced by the residual shear strength.

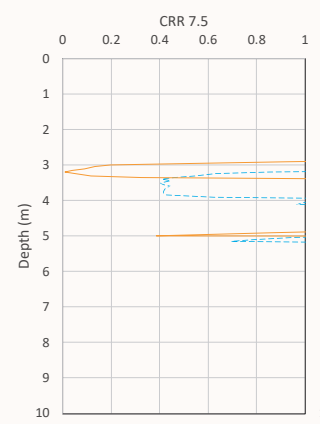

a)

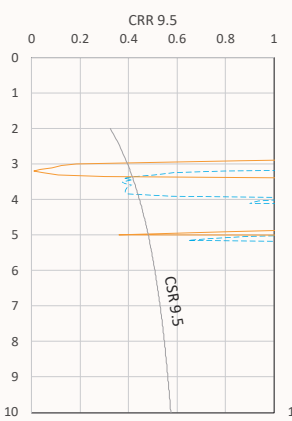

b)

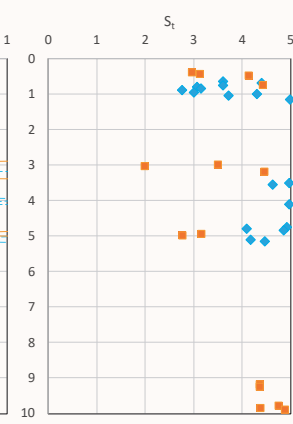

c)
Figure 4: Cyclic failure assessment. a) Cyclic Resistance Ratio $C R R$ for $M=7.5$, b) $C R R$ for $M \sim 9.5$ and Cyclic Stress Ratio $C S R$ corresponding to a $M \sim 9.5$ and $\mathrm{PGA} \sim 0.5 \mathrm{~g}$, and c) soil sensitivity

\section{Liquefaction failure of saturated granular solls}

To examine the potential for different ground failure modes we examined the same sCPTu soundings and evaluated the liquefaction hazard. Seismic liquefaction occurs in saturated sandy soils when the cyclic stress exceeds the cyclic resistance, resulting in high excess pore pressures and large strain potential. Liquefaction occurs in soils that are granular and controlled mainly by gravity and not by colloidal forces, therefore a plasticity index PI of less than 8 to 12 . The same has been found in the liquefaction potential analysis of tailings dams, commonly used in Chile (Villavicencio et al., 2016).

Using the same loading criteria, we plot the CSR using equation (1). To evaluate the cyclic resistance we follow the methods presented in Moss et al. (2006). A probability of liquefaction of $15 \%$ is used as the equivalent deterministic threshold and the $C R R$ is calculated as: where $q_{c, l}$ is the stress corrected tip resistance within the liquefiable layer, $R_{f}$ is the friction ratio, $c$ is the normalizing exponent, $M_{w}$ is the earthquake moment magnitude, $\sigma_{v}^{\prime}$ is the vertical effective stress, and $\Phi^{-1}\left(P_{L}\right)$ is the inverse cumulative normal distribution function for a given probability of liquefaction [NORMINV(PL, 0,1$)$ in Excel].

The results are shown in Figure 5. From the assumed water table at $2 \mathrm{~m}$ down to $3 \mathrm{~m}$, and then from 3.5 to $5 \mathrm{~m}$ we see layers where liquefaction is likely for non-plastic to lowplastic soils and this loading situation. Deeper liquefaction is also likely, but it is not as commonly observed at the ground surface based on prior liquefaction case histories (Moss et al., 2006).

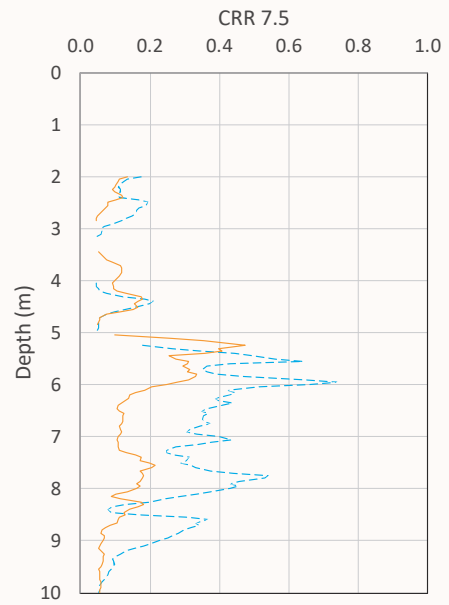

a)

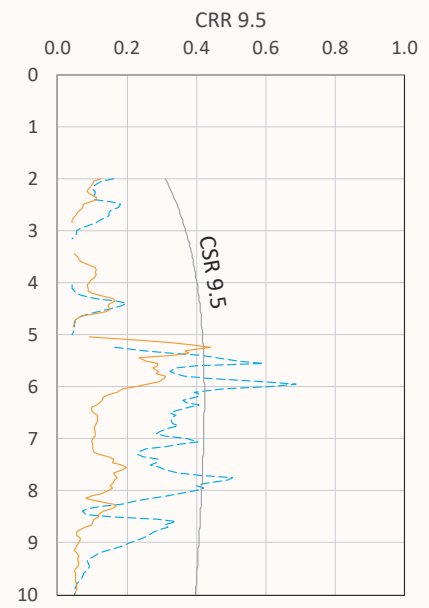

b)
Figure 5: Liquefaction triggering assessment. a) Cyclic Resistance Ratio $C R R$ for $M=7.5$ and b) $C R R$ for $M \sim 9.5$, the Cyclic Stress Ratio CSR corresponding to a $M \sim 9.5$ and PGA $0.5 \mathrm{~g}$

\section{Comparison of ground failure mechanisms}

Two ground failure mechanisms, cyclic failure of plastic soils and liquefaction failure of granular soils, have been presented. Both indicated the potential for failure in future large events. But which caused the damage in 1960 and which is a hazard to mitigate in future events?. This all depends on the plasticity of the soil and the thickness of the layers.

The soils in Valdivia, based on old investigations and more recent investigations, are highly variable and interlayered

$$
\begin{aligned}
& C R R \\
& =\exp \left\{\frac{\left[q_{c, 1}^{1.045}+q_{c, 1}\left(0.110 R_{f}\right)+\left(0.001 R_{f}\right)+c\left(1+0.85 R_{f}\right)-0.848 \ln \left(M_{w}\right)-0.002 \ln \left(\sigma_{v}^{\prime}\right)-20.923+1.632 \Phi^{-1}\left(P_{L}\right)\right]}{7.177}\right\}
\end{aligned}
$$


river and manmade deposits that tend to be on the plastic end of the spectrum. Cyclic failures in past events do not require significant layer thickness to result in a sliding surface for deformations to develop. Cyclic failure does however require driving shear stresses to develop seismic induced deformations. These driving shear stresses would be from sloping ground, free face conditions, or building induced stresses.

For liquefaction to result in large deformations the soil needs to have low-plasticity and generally the saturated layers need to be upwards of a meter thick. Recent events in New Zealand (Green et al., 2014) have pointed out the limitations of current liquefaction triggering methods when assessing interlayered deposits. These studies have shown that current methods like Moss et al. (2006) tend to overestimate the likelihood of triggering when interlayered silts and sands are present, as opposed to "clean" sands layers greater than a meter thick.

For Valdivia, detailed subsurface sampling is recommended for each project to test for the layer thickness and plasticity of the layers to determine how to proceed. It appears that both failure mechanisms have been and will be present, which is similar to the soil conditions and past seismic behavior in Anchorage Alaska. The questions then becomes, which mechanism controls and how much deformation is expected? For liquefaction deformations Yazdi and Moss (2016) can be used to estimate deformations. For sloping ground or free face conditions it is typical to use a lateral spreading model (Youd et al., 2002). For cyclic failure, Newmark-type semi-empirical methods (e.g., Makdisi and Seed, 1979; Bray et al., 1995; Bray and Travasarou, 2007) have had some success providing a rough order of magnitude, as well as numerical modeling using a finite difference approach (e.g., FLAC) to provide a more calibrated assessment.

\section{Co-seismic tectonic deformations}

Although it has been noted anecdotally since antiquity that co-seismic displacements accompany large earthquakes, only recently has modern geodesy allowed for the accurate measurement of these displacements (Kelson et al., 2011). The 2010 Maule earthquake caused vertical and horizontal co-seismic displacements that were measured at sufficient enough locations using GPS to resolve some of spatial characteristics. The crustal deformation has a pattern that resembles that of an elastic or harmonic response. Similar to the utility of the elastic rebound theory for earthquake stick-slip response (Hough and Bilham, 2005), and the isostatic rebound modeling of crust when unloaded after glacial retreat (Larsen et al., 2005), post-seismic tectonic uplift/subsidence lends towards a large-scale elastic interpretation as well.

Data from the 2010 Maule event (after Vigny et al., 2011) is shown in Figure 6. The data is plotted as the perpendicular distance from the trench in kilometers versus the co-seismic displacement in meters. The data is an aggregate of two cross-sections, one at the latitude of Constitucion $\left(35.5^{\circ} \mathrm{S}\right.$ to $\left.36.0^{\circ} \mathrm{S}\right)$ and the other at the latitude of Concepcion $\left(37.0^{\circ} \mathrm{S}\right.$ to $\left.37.5^{\circ} \mathrm{S}\right)$.

Valdivia is located roughly $150 \mathrm{~km}$ perpendicular from the trench. If the 2010 event is a good analog of the 1960 event (e.g., both along the same subduction trench and rupturing with the same planar orientation) then Valdivia plots to the right of the maximum co-seismic subsidence. Preliminary research on other subduction events, 2004 Sumatra (Chlieh et al., 2007) and 2011 Tohoku (Nishimura et al., 2011), the authors have observed that the location and magnitude of maximum subsidence has a dependence on the seismic moment magnitude (Figure 7). This observation would corroborate the greater measured subsidence in Valdivia in 1960 being on the order of $1.8 \mathrm{~m}$ (Retamal and Kausel, 1969).

The pattern observed in Figure 6 has a very curious shape,

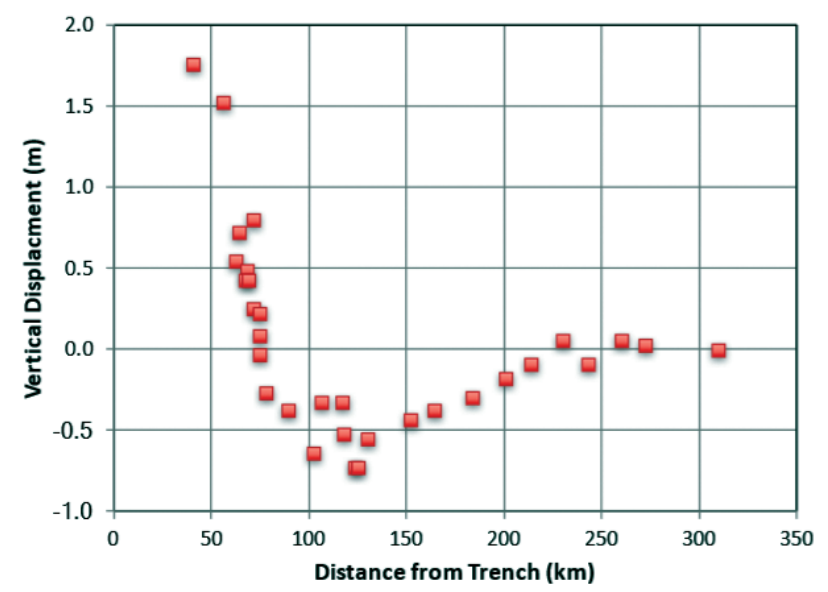

Figure 6: Plot of vertical co-seismic tectonic deformations (m) as a function of fault-perpendicular distance from the trench (km) from the 2010 Maule earthquake (after Vigny et al., 2011) 


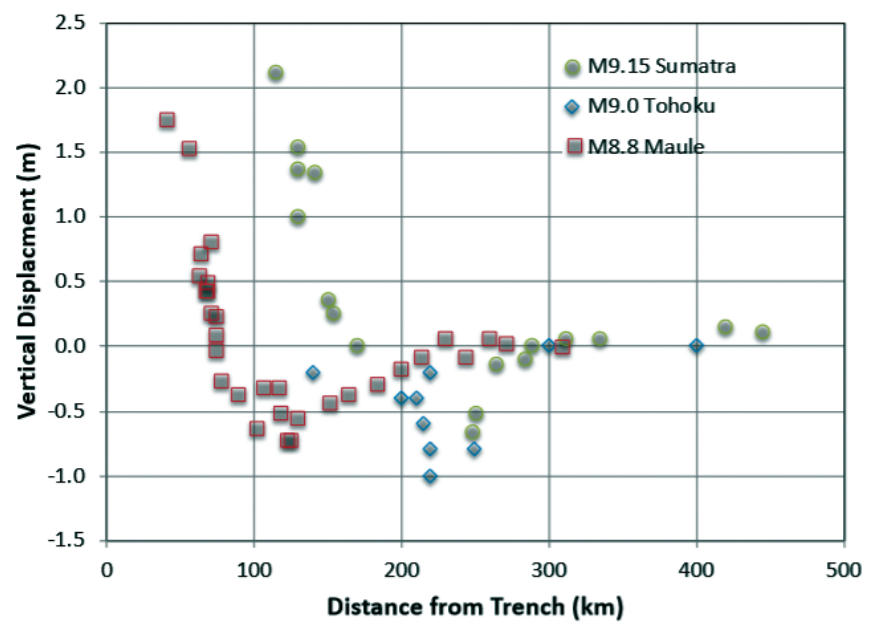

Figure 7: Comparison plot of the co-seismic tectonic deformations from the 2004 Sumatra, 2011 Tohoku, and 2010 Maule earthquakes

not following a simple exponential decay or similar physical process. The shape lends to being modeled by a damped harmonic function, which is commonly used in structural dynamics to explain the response of structural components/systems that have some stiffness and some damping (Chopra, 1995, p. 339). Damping is a "catch all" term used to describe some mechanism by which energy is dissipated in a structural component/system, and includes both frequency dependent and frequency independent mechanisms. The mathematical function that describes an under-damped harmonic oscillator is:

$$
x(t)=e^{-\zeta \omega_{0} t}\left(A \cos \left(\omega_{d} t\right)+B \sin \left(\omega_{d} t\right)\right)
$$

where

$$
\begin{aligned}
& \omega_{d}=\omega_{0} \sqrt{1-\zeta^{2}} \\
& A=x(0) ; \text { and } B=\frac{1}{\omega_{d}}\left(\zeta \omega_{0} x(0)+\dot{x}(0)\right)
\end{aligned}
$$

and $x=$ displacement, $\dot{x}=$ velocity, $t=$ time, which in this application is equated to distance, $\zeta=$ damping ratio (ratio of critical damping), $\omega_{0}=$ undamped angular frequency, $\omega_{d}=$ damped frequency, $A$ and $B=$ determined by initial conditions, which in this case is under-damped.

The utility of this function (6) becomes apparent when it is fit to the co-seismic data. As can be seen in Figure 8 the function (6) can mimic the observed peak uplift, peak subsidence, and approach to zero with reasonable accuracy (nonlinear regression fit with $R^{2} \cong 0.9$ ). This function also captures the observed uplift that occurs at a distance greater than that of peak subsidence before the approach to zero.

The 1960 earthquake event released significantly more energy than the 2010 event, and likely had much larger co-seismic deformations associated with it. However the trends appear to hold true when compared to other events (2005 Sumatra and 2011 Tohoku, not shown). There appears to be a magnitude, or more precisely a seismic moment magnitude dependence, and the amplitude and location of the trough modeled in Figure 8. Valdivia is roughly 150 $\mathrm{km}$ from the trench which would put it near the region of largest subsidence, agreeing with the measured $1.8 \mathrm{~m}$ of tectonic subsidence (Retamal and Kausel, 1969). The hope is that continued careful measurements of co-seismic displacements will result in a sufficient database to create predictive functions for forecasting these often hazardous surface displacements.

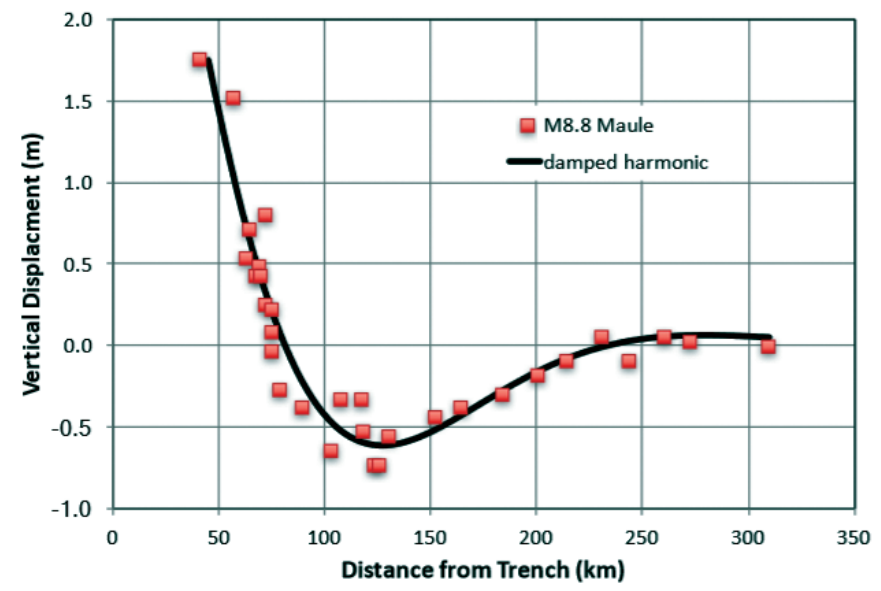

Figure 8: Co-seismic deformation data from 2010 Maule event fit with a damped harmonic oscillator function using nonlinear regression $\left(\mathrm{R}^{2}=0.9\right)$

\section{Summary}

Based on a review of the documented ground failures and tectonic subsidence, and using current methods to assess these effects, it appears that a repeat of the 1960 Chilean earthquake would result in very similar ground failure and subsidence in Valdivia. The widespread presence of silty soils and past use of these as fill material puts the city at risk for cyclic failure of plastic fined grained soils. These failures result in ground cracking and lateral deformations where driving shear stresses are present such as along free 
faces, on sloping ground, or below building foundations. There is also liquefaction hazard of saturated granular soils that are non-plastic to low-plastic in nature throughout the city. Sand boils, ground cracking, and lateral spreading are the liquefaction effects that can cause damage. The location of the city with respect the subduction trench places it in a region that is susceptible to co-seismic tectonic subsidence and increased tsunami hazard. The biggest hurdle in mitigating most seismic hazards is often awareness, and Chilenos are frequently reminded that they live in a dynamic crustal environment that produces some of the worlds' largest earthquakes. The goal of this paper was to provide some insight into the specific hazards in the Valdivia region, and apply some current engineering tools for analyzing these hazards.

\section{References}

Arenas, M., Milovic, J., Pérez, Y., Troncoso, R., Behlau, J., Hanisch, J. and Helms, F. (2005). Geología para el ordenamiento territorial: área de Valdivia, Región de Los Lagos. Servicio Nacional de Geología y Minería SERNAGEOMIN, Carta Geológica de Chile, Serie Geología Ambiental 8: 71p., 6 mapas escala 1:100.000 y 1 mapa escala 1:25.000.

Boulanger, R.W. and Idriss, I.M. (2004). Evaluating the potential for liquefaction or cyclic failure of silts and clays. Report UCD/CGM-04/ 01, Department of Civil and Environmental Engineering, University of California at Davis, USA

Bray, J.D. and Travasarou, T. (2007). Simplified procedure for estimating earthquake-induced deviatoric slope displacements. Journal of Geotechnical and Geoenvironmental Engineering 133(4), 381-392

Bray, J.D. and Sancio, R.B. (2006). Assessment of the liquefaction susceptibility of fine-grained soils. Journal of Geotechnical and Geoenvironmental Engineering 132(9), 1165-1177

Bray, J.D., Augello, A.J., Leonards, G.A., Repetto, P.C. and Byrne, R.J. (1995). Seismic stability procedures for solid-waste landfills. Journal of Geotechnical Engineering 121(2), 139-151

Chlieh, M, Avouac, J.P., Hjorleifsdottir, V., Song, T.R.A., Ji, C., Sieh, K., Sladen, A., Hebert, H., Prawirodirdjo, L., Bock, Y. and Galetzka, J. (2007). Coseismic slip and afterslip of the great $M_{\mathrm{w}} 9.15$ Sumatra-Andaman earthquake of 2004. Bulletin of the Seismological Society of America 97(1A), 152-173
Chopra, A.K. (1995). Dynamics of structures. New Jersey: Prentice Hall

Duke, C.M. and Leeds, D.J. (1963). Response of soils, foundations, and earth structures to the Chilean earthquakes of 1960. Bulletin of the Seismological Society of America 53(2), 309-357

González, J. y Verdugo, R. (2014). Sitios afectados por licuefacción a causa del terremoto 27-F. VIII Congreso Chileno de Ingeniería Geotécnica, Santiago, Chile, artículo A26

Green, R.A., Cubrinovski, M., Cox, B., Wood, C., Wotherspoon, L., Bradley, B. and Maurer, B. (2014). Select liquefaction case histories from the 2010-2011 Canterbury earthquake sequence. Earthquake Spectra 30(1), 131-153

Holtz, R.D., Kovacs, W.D. and Sheahan, T.C. (2011). An introduction to geotechnical engineering. Pearson, N.J., USA

Hough, S.E. and Bilham, R.G. (2005). After the earth quakes: elastic rebound on an urban planet. Oxford University Press

IDIEM (1961). On borings and soil tests in Valdivia along Avenida Costanera between San Carlos St. and the Isla Teja Bridge. Report No. 4,836, July 7, 1961, University of Chile, Unpublished

Idriss, I.M. and Boulanger, R.W. (2008). Soil liquefaction during earthquakes. EERI Monograph MNO-12, Berkeley, USA

Kelson, K., Witter, R.C., Tassara, A., Ryder, I., Ledezma, C., Montalva, G., Frost, D., Sitar, N., Moss, R. and Johnson, L. (2012). Coseismic tectonic surface deformation during the 2010 Maule, Chile, $\mathrm{M}_{\mathrm{w}} 8.8$ earthquake. Earthquake Spectra 28(1), 3954

Larsen, C.F., Motyka, R.J., Freymueller, J.T., Echelmeyer, K.A. and Ivins, E.R. (2005). Rapid viscoelastic uplift in southeast Alaska caused by post-Little Ice Age glacial retreat. Earth and Planetary Science Letters 237(3-4), 548-560

Leyton, F., Ruiz, S. and Sepúlveda, S.A. (2009). Preliminary reevaluation of probabilistic seismic hazard assessment in Chile: from Arica to Taitao Peninsula. Advances in Geoscience 22, 147153

Lunne, T., Robertson, P.K. and Powell, J.J.M. (1997). Cone penetration testing in geotechnical practice. Blackie Academic. EF Spon/Routledge, NY, USA 
Makdisi, F.I. and Seed, H.B. (1979). Simplified procedure for evaluating embankment response. Journal of the Geotechnical Engineering Division 105(12), 1427-1434

Moss, R.E.S., Chen, G-X. and Tong, L-Y. (2011). Comparing liquefaction procedures in the US and China. Journal of Sichuan University of Science and Engineering (Natural Science Edition) 24(1)

Moss, R.E.S., Seed, R.B., Kayen, R.E., Stewart, J.P., der Kiureghian, A. and Cetin, K.O. (2006). CPT-based probabilistic and deterministic assessment of in situ seismic soil liquefaction potential. Journal of Geotechnical and Geoenvironmental Engineering 132(8), 1032 - 1051

Nishimura, T., Munekane, H. and Yarai, H. (2011). The 2011 off the Pacific coast of Tohoku earthquake and its aftershocks observed by GEONET. Earth, Planets and Space 63, 631-636

Retamal, E. and Kausel, E. (1969). Vibratory compaction of the soil and tectonic subsidence during the 1960 earthquake in Valdivia, Chile. In 4th World Conference on Earthquake Engineering, Santiago, Chile, 13-28

Robertson, P.K. and Cabal, K.L. (2015). Guide to cone penetration testing for geotechnical engineering. $6^{\text {th }}$ edition. Gregg Drilling \& Testing, Inc. California, USA (http://www.cpt-robertson.com) Seed, H.B. and Idriss, I.M. (1971). Simplified procedure for evaluating soil liquefaction potential. Journal of Soil Mechanics and Foundations Division 97(9), 1249-1273
Seed, R.B., Cetin, K.O., Moss, R.E., Kammerer, A.M., Wu, J., Pestana, J.M., Riemer, M.F., Sancio, R.B., Bray, J.D., Kayen, R.E. and Faris, A. (2003). Recent advances in soil liquefaction engineering: a unified and consistent framework. In Proceedings of the 26th Annual ASCE Los Angeles Geotechnical Spring Seminar: Long Beach, CA, USA

USGS (2017). https://earthquake.usgs.gov/earthquakes/browse/ largest-world.php, accessed 6/1/2017

Vigny, C., Socquet, A., Peyrat, S., Ruegg, J.C., Métois, M., Madariaga, R., Morvan, S., Lancieri, M., Lacassin, R., Campos, J., Carrizo, D. et al. (2011). The $2010 M_{\mathrm{w}} 8.8$ Maule megathrust earthquake of Central Chile, monitored by GPS. Science 332(6036), 1417-1421

Villavicencio, G., Breul, P., Bacconnet, C., Fourie, A. and Espinace, R. (2016). Liquefaction potential of sand tailings dams evaluated using a probabilistic interpretation of estimated in-situ relative density. Journal of Construction 15(2), 9-18

Yazdi, J.S. and Moss, R.E.S. (2016). Nonparametric liquefaction triggering and postliquefaction deformations. Journal of Geotechnical and Geoenvironmental Engineering 143(3), 04016105

Youd, T.L., Hansen, C.M. and Bartlett, S.F. (2002). Revised multilinear regression equations for prediction of lateral spread displacement. Journal of Geotechnical and Geoenvironmental Engineering 128(12), 1007-1017 